\title{
MEMBERDAYAKAN POTENSI KELUARGA MELALUI PARTISIPASI DAN KESADARAN LINGKUNGAN MASYARAKAT DI DESA CIMANGGU II
}

\author{
Freza Riana ${ }^{1}$, Siti Herawati, Devi Amaliah ${ }^{2}$ \\ zarianafre@gmail.com \\ Dosen Fakultas Teknik ${ }^{1}$, Mahasiswa KKN Kelompok 28 Tahun $2018^{2}$
}

\begin{abstract}
ABSTRAK
Tulisan ini memotret sebuah pemberdayaan mulai dari potensi keluarga, lingkungan masyarakat setempat, bahwa kita ketahui pemberdayaan adalah salah satu tujuan untuk mencapai kesejahteteraan masyarakat yang ada. Kemiskinan dalam hidup sudah ada sejak masa pra kemerdekaan sampai pascakemerdekaan. Banyak cara yang sudah dilakukan oleh pemerintah dalam menangani masalah tersebut. Untuk mencapai kesejahteraan dibutuhkan prinsip-prinsip sebagai landasan dalam melakukan pemberdayaan. Menurut Jim Ife setidaknya ada lima prinisip pemberdayaan masyarakat, mulai dari prinsip ekologis, keadilan sosial, kearifan lokal, proses, lokal dan global. Keluarga adalah kumpulan dua orang atau lebih yang hidup bersama dengan keterikatan aturan dan emosional dan individu mempunyai peran masing - masing yang merupakan bagian dari keluarga. Definisi operasional dari pemberdayaan keluarga merupakaan upaya untuk menjalankan peran sesuai dengan fungsinya dalam keluarga, dan mengembangkan potensi-potensi yang dimiliki anggota keluarga secara maksimal, sehingga terbentuk ketahanan keluarga itu sendiri. Dalam rangka menghadapi tantangan lingkungan di bumi, ada kebutuhan untuk mendidik dan memberi informasi kepada masyarakat mengenai permasalahan lingkungan. Masyarakat dan pemerintah dalam menjaga bumi dari pencemaran dan kerusakan adalah melalui pelaksanaan menjaga Lingkungan Hidup, yang merupakan kunci untuk mempersiapkan masyarakat dengan pengetahuan, keahlian, nilai dan sikap peduli lingkungan sehingga dapat berpartisipasi aktif dalam memecahkan masalah lingkungan
\end{abstract}

\section{Kata Kunci: Pemberdayaan, Potensi Keluarga, Masyarakat}

\section{PENDAHULUAN}

Pemberdayaan adalah salah satu tujuan untuk mencapai kesejahteteraan masyarakat yang ada. Kemiskinan dalam hidup sudah ada sejak masa pra kemerdekaan sampai pascakemerdekaan. Banyak cara yang sudah dilakukan oleh pemerintah dalam menangani masalah tersebut. Untuk mencapai kesejahteraan dibutuhkan prinsip-prinsip sebagai landasan dalam melakukan pemberdayaan. Menurut Jim Ife setidaknya ada lima prinisip pemberdayaan masyarakat.

\section{Prinsip ekologis}

prinisp yang menekankan pada pelestarian lingkungan yang ada. Hubungan antara masyarakat dengan lingkungan harus dijaga sehingga menimbulkan keseimbangan keduanya. 


\section{Prinsip Keadilan sosial}

Keadilan makin sulit untuk ditemukan, banyak masyarakat menengah ke bawah belum menadapatkan keadilan. Prinisp ini, menekankan pada keadilan seharusnya didapatkan oleh masyarakatseluruhnya tanpa terkecuali. Prinsip ini juga mempunyai kesamaan dalam UUD (undang-undang dasar).

\section{Prinsip Kearifan lokal}

Sebuah revolusi dalam pemberdayaan, tidak harus mengubah tatanan yang sudah ada dalam sebuah masyarakat atau kelompok. Pemberdayaan harus menjaga dan memadukan sesuatu yang sudah ada tanpa harus menghilangkannya. Dalam pemberdayaannya masyarakat akan menerima itu sebagai perubahan yang positif bukan negatif.

\section{Prinsip Proses}

Proses adalah prinsip yang paling penting dalamkegiatan dan aktifitas termasuk dalam pemberdayaan. Berhasil tidaknya pemberdayaan bergantung pada proses sebuah pemberdayaa masyarakat. Hasil dari proses pemberdayaan adalah kesejahteraan masyrakat.

\section{Prinisip Lokal dan Global}

Persaingan sekarang ini sangat bebas dan terbuka, siapapun bisa bersaing tanpa terkecuali, kekurangsiapan dari masyarakat lokal akan membuat kehidupan semakin sulit untuk mereka. Kondisi ini harus mereka siasati, di antaranya dengan membekali masyarakat lokal dengan pengetahuan yang mumpuni.

\footnotetext{
Masalah-masalah yang sering muncul di negara Indonesia adalah kemiskinan. Kemiskinan sudah lama terjadi dan belum ada solusi yang tepat.
}

Ada dua pendekatan dalam melihat penyebab kemiskinan. Pertama, kemiskinan merupakan akibat kultural seperti sifat malas, kurangnya kemampuan inetelektual, kelemahan fisik, kurangnya keterampilan dan rendahnya kemampuan dalam menanggapi persoalan hidup di sekitarnya. Kedua melihat kemiskinan bersumber dari ketimpangan struktural seperti kebijakan pemerintah yang kurang berpihak pada orang miskin, struktur masyarakat yang diskriminatif dan lain sebagainya. Dua masalah ini selalu menjadi sumber yang paling utama. Salah satu faktor penting solusi masalah kemiskinan yang ada di Indonesia adalah dengan melakukan pemberdayaan yang bertolak dari bawah ke atas.

Pemberdayaan bisa dikatakan sebagai usaha untuk memberi kesempatan serta kemampuan pada kelompok masyarakat yang dalam hal ini keluarga miskin untuk mampu dan berani bersuara dalam menyampaikan gagasan dan pendapat mereka serta memiliki keberanian untuk memilih suatu baik itu dalam bentuk metode,produk,tindakan maupun konsep yang dipandang terbaik tidak hanya pada keluarga dan pribadinya tapi juga bagi masyarakatnya. Adapun potensi keluarga kita lihat dari definisi keluarga yaitu menurut Departemen Kesehatan dalam Effendy (1998), mendefinisikan keluarga sebagai unit terkecil dari masyarakat, terdiri atas kepala keluarga dan beberapa orang yang berkumpul dan tinggal disuatu tempat dibawah suatu atap dalam keadaan saling ketergantungan. Menurut Friedman dalam Suprajitno (2004), mendefinisikan bahwa keluarga adalah kumpulan dua orang atau lebih yang hidup bersama dengan keterikatan aturan dan emosional dan individu mempunyai peran masing - 
masing yang merupakan bagian dari keluarga.

Definisi operasional dari pemberdayaan keluarga merupakaan upaya untuk menjalankan peran sesuai dengan fungsinya dalam keluarga, dan mengembangkan potensi-potensi yang dimiliki anggota keluarga secara maksimal, sehingga terbentuk ketahanan keluarga itu sendiri Keluarga adalah kumpulan dua orang atau lebih yang hidup bersama dengan keterikatan aturan dan emosional dan individu mempunyai peran masing - masing yang merupakan bagian dari keluarga.

Dalam rangka menghadapi tantangan lingkungan di bumi, ada kebutuhan untuk mendidik dan memberi informasi kepada masyarakat mengenai permasalahan lingkungan. Masyarakat dan pemerintah dalam menjaga bumi dari pencemaran dan kerusakan adalah melalui pelaksanaan menjaga Lingkungan Hidup, yang merupakan kunci untuk mempersiapkan masyarakat dengan pengetahuan, keahlian, nilai dan sikap peduli lingkungan sehingga dapat berpartisipasi aktif dalam memecahkan masalah lingkungan

Desa Cimanggu II berada di daerah Kecamatan Cibungbulang Kabupaten Bogor, Desa Cimanggu II dimana tempat kantor cibungbulang berada, desa Cimanggu II terdiri dari $8 \mathrm{Rw}$ dan masingmasing RW sebagian besar terdiri dari 5 RT. Lokasi tempat kami melaksanakan KKN terintegrasi ini berada di wilayah RW 01 yang terdiri dar RT 05- RT 09. Keadaan lingkungan di RW 01 bisa kita katakan seperti sebuah kampung yang ada di perkotaan karena keadaan lingkungan dan masyarakat yang sudah lumayan maju dan modern, selain itu karena termasuk ke dalam kecamatan Cibungbulang yang kita ketahui dekat dengan Pertokoan maka
diCimanggu II ini khususnya di RW 01 mudah untuk melengkapi kebutuhan sehari-hari.

\section{Kondisi Masyarakat}

Dalam bidang pendidikan kondisi masyarakat RW 01 Desa cimanggu II bisa dibilang terbagi menjadi dua golongan yaitu warga pribumi dan warga pendatang. Warga pribumi sebagian besar berprofesi sebagai pedagang, sedangkan warga pendatang profesinya bermacammacam seperti, PNS, pedagang, beruh pabrik. Bila dulu warga pribumi lebih mendominasi dibandingkan warga pendatang bila di persenkan sekitar $70 \%$ warga pribumi dan $30 \%$ warga pendatang namun untuk saat ini sekitar 50\%-50\% karena banyak warga pribumi yang menjual tanah atau membangu tanah menjadi konterkan yang disewakan kepada pendatang.. Meskipun terdiri dari dua golongan semangat gotong royong warga RW 01 ini sangatlah baik, seperti pada acara HUT RI yang ke 73 kemarin warga-warga bergotong royong memeriahkan acara kemerdekaan bangsa Indonsesia ini dengan penuh semangat gotong royong.

Dalam hal pendidikan di RW 01 Desa Cimanggu II ini cukup baik karena tidak ada anak yang tidak bersekolah, rata-rata pendidikan warga RW 01 yaitu SMA/sederajat meskipun ada juga yang sampai SMP dan bahkan ada pula yang sampai perguruan tinggi, hal ini dikarenakan di RW 01 sarana pendidikan yang cukup memadai seperti PAUD, MI, MTS, dan SMK, selain itu khusus MI dan SMP Al- Badariyah, mereka meringankan biaya sekolah sehingga banyak anak-anak yang tidak putus sekolah dikarenakan masalah ekonomi. Untuk masalah Agama di RW 01 sangat 
baik dengan antusias dari mulai pengajian anak-anak, ibu-ibu, dan bapak- bapak, semuanya berjalan dengan baik sesuai dengan jadwal masing-masing namun yang di sayangkan adalah tidak adanya pengajian untuk pemuda dan remaja, sehingga banyak remaja yang tidak terbatasi pergaulannya.

Dalam bidang ekonomi masyarakat Desa Cimanggu II tepatnya Rw 01 terdiri dari warga pribumi dan warga pendatang, profesi warga pribumi yaitu buruh atau pedagang, petani kebun, kuli bangunan. Sedangkan yang pendatang banyak yang berprofesi sbagai pegawai negri sipil, bila diamati dengan pengambilan kesimpulan bahwa rata-rata pendidikan SMA namun banyak pula yang sampai peruruan tinggi

Dalam hal kesehatan di RW 01Desa Cimanggu II tepatnya di RW 01 ini cukup baik, karena sebagian besar orang tua yang memiliki anak selau rutin ikut serta membawa anaknya dalam kegiatan posyandu yang diadakan setiap bulannya. Hal ini juga terlihat saat kegiatan penyuntikan imuniasasi campak dan rubella (MR).

Dalam hal lingkungan, sudah cukup baik, semangat gotong royong warga RW 01 sangatlah baik, seperti pada acara HUT Ri yang ke 73, warga-warga bergotong royong memeriahkan acara kemerdekaan indonesia dengan penuh semangat, tetapi sangat disayangkan wilayah RW01 sudah padat penduduk sehingga sedikit lahan kosong untuk dimanfaatkan nya.

\section{METODE PENGABDIAN}

Salah satu faktor yang dapat mendukung tercapainya sasaran kegiatan pemberdayaan masyarakat dengan kami kelompok kkn 28 terjun di masyarakat sangat di pengaruhi oleh jenis pendekatan yang di gunakan dalam melakukan kegiatan tersebut.

Dalam hal ini pendekatan yang di maksud terkait dengan cara yang di gunakan agar supaya masyarakat yang menjadi kelompok sasaran kegiatan pemberdayaan bersikap terbuka dalam menerima berbagai bentuk unsur inovasi yang semuanya itu di maksudkan agar supaya mereka dapat melepaskan diri dari berbagai aneka rupa keterbelakangan, isolasi sosial, keterpurukan serta ketertinggalan dalam berbagai sektor masyarakat. Oleh sebab itu untuk memilih pendekatan yang di nilai cocok dengan kondisi sosial ekonomi dan budaya kelompok sasaran Masyarakat

Strategi pembangunan yang bertumpu pada pemberdayaan masyarakat dipahami sebagai proses transformasi dalam hubungan sosial, ekonomi, budaya dan politik masyarakat, sehingga perubahan struktural yang terjadi diharapkan merupakan proses yang berlangsung secara alami. Teori-teori ekonomi makro memerlukan intervensi yang tepat sehingga kebijaksanaan pada tingkat makro mendukung upaya menutup kesenjangan melalui kegiatan-kegiatan yang bersifat mikro yang langsung ditujukan kepada masyarakat lapisan bawah, sehingga pemberdyaan masyarakat (empowering) sebagai model pembangunan dapat menjadi jembatan bagi konsep-konsep pembangunan makro dan mikro.

Pendekatan utama dari konsep pemeberdayaan adalah "masyarakat tidak dijadikan obyek dari proyek pembangunan tetapi merupakan subyek dari pembangunannya sendiri”. Berdasarkan pada konsep pemberdayaan masyarakat sebagai model pendekatan yang dipakai adalah : 
Pertama, targeted artinya upayanya harus terarah kepada yang memerlukan dengan program yang dirancang untuk mengatasi masalahnya dan sesuai kebutuhannya.

Kedua, mengikutsertakan bahkan dilaksanakan oleh masyarakat yang menjadi sasaran. Tujuannya adalah supaya bantuan efektif karena sesuai kebutuhan mereka yang sekaligus meningkatkan keberdayaan (empowering) masyarakat dengan pengalaman dalam merancang, melaksanakan, mengelola dan mempertangung jawabkan upaya peningkatan diri dan ekonominya.

Ketiga, menggunakan pendekatan kelompok, karena secara individual masyarakat. Disamping itu kemitraan usaha antar kelompok dengan kelompok yang lebih baik saling menguntungkan dan memajukan kelompok.

Selanjutnya untuk kepentingan analisis pemberdayaan masyarakat (empowering) harus dilakukan baik dengan pendekatan Komprehensif Rasional maupun Inkremental.

\section{REALISASI PROGRAM}

Pendidikan: program yang sudah terlealisasi yaitu Pembaharuan Majlis Ta'lim/TPA, pembantuan pengajaran disekolah salah satunya di SMP AlBadariyah dengan mata pelajaran yang berbeda-beda mulai dari Bahsa Inggris, Bahasa Arab, PKN, maupun PAI, dan Pengajaran TPA, bukan hanya pengajaran cara baca tulis al-qur'an melainkan pembelajaran hadits mapun kosa kata bahasa arab dan inggris.

Ekonomi: Program yang sudah terlealisasikan yaitu strategi pemasaran UMKM, dan penyuluhan kewirausahan ekonomi kepada masyarakat Desa Cimanggu II

Kesehatan: Program yang sudah terlealisasikan yaitu vaksin rubela MR yang dilakukan di SMP Al-Badariyah, dan pogram PHBS berupa cuci tangan yang dilakukan di MI Al-Badariyah

Pemberdayaan Lingkungan : Program yang sudah terlealisasikan yaitu pembuatan lomba agustusan, perenovasian MCK, dan pembuatan Plang jalan untu desa Cimanggu II

Adapun program unggulan kami yaitu perenovasian MCK, dan Pembaharuan Majlis Ta'lim/TPA dengan tujuan itulah yang sangat dipentingkan di masyarakat Desa Cimanggu II

Agama : program yang sudah terlealisasikan yaitu mengadakan pengajian majlis ta'lim setiap hari sabtu dan pengkajian kitab fathul qorib.

\section{Dokumentasi Perprogram}

\section{Pendidikan}

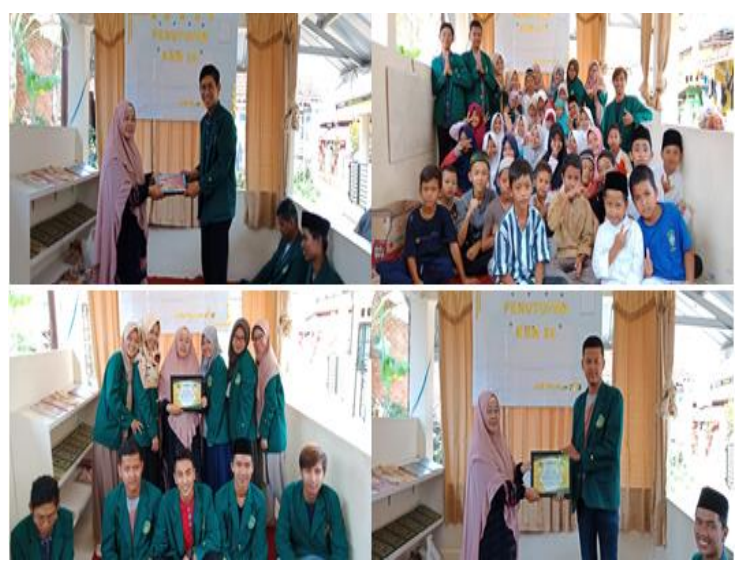

Pembaharuan Majlis Ta'lim 


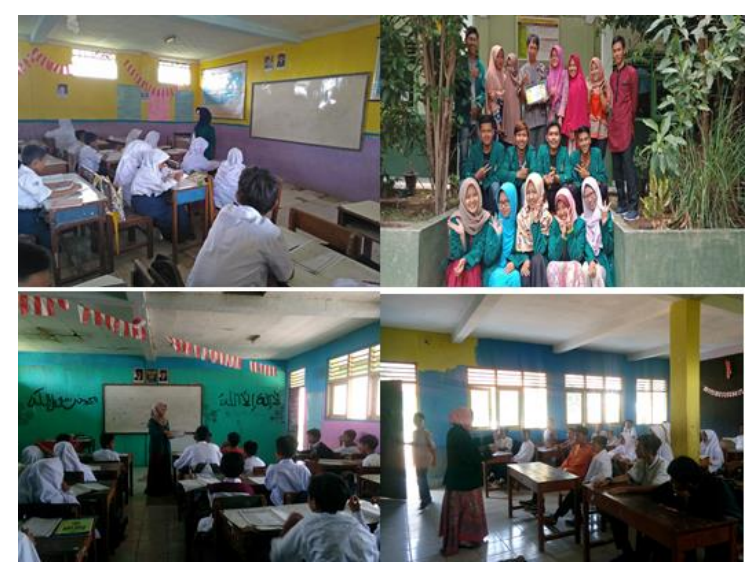

Pembantuan Pengajaran di Sekolah

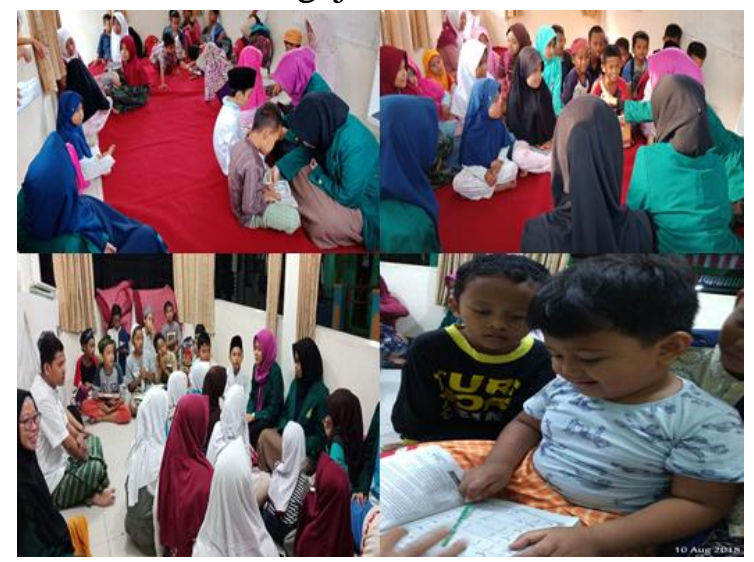

Pengajaran TPA

\section{Ekonomi}

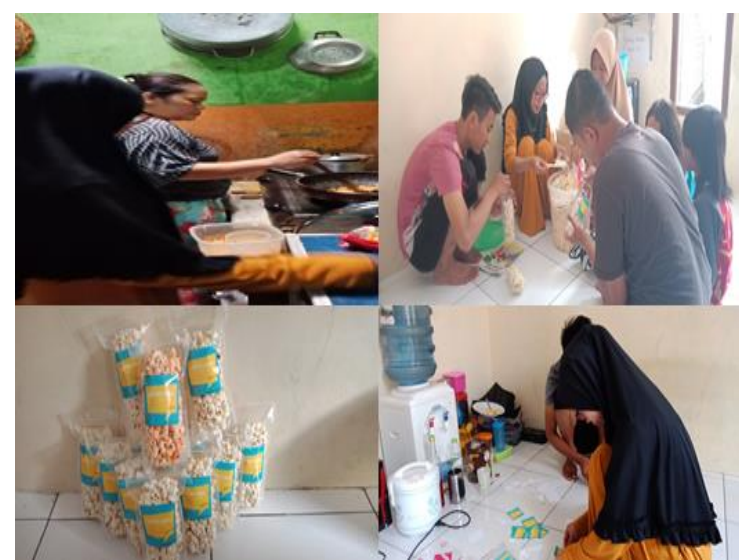

Pemasaran UMKM

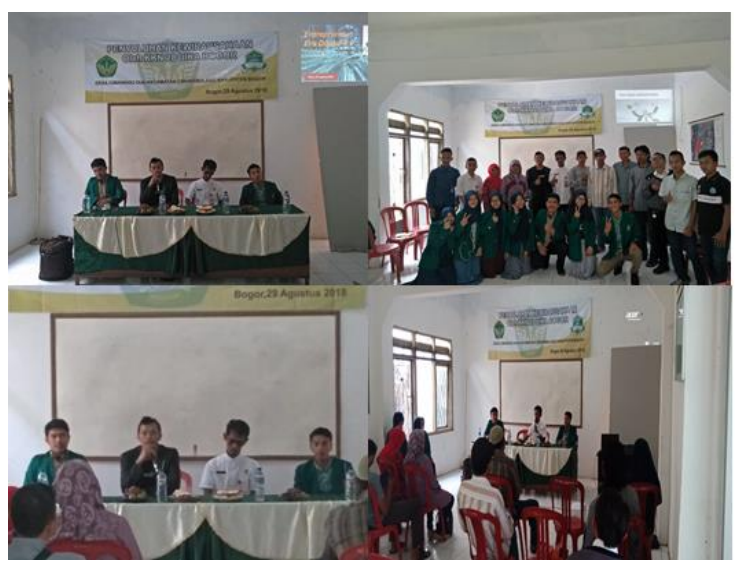

Penyuluhan Kewirausahaan

\section{Kesehatan}

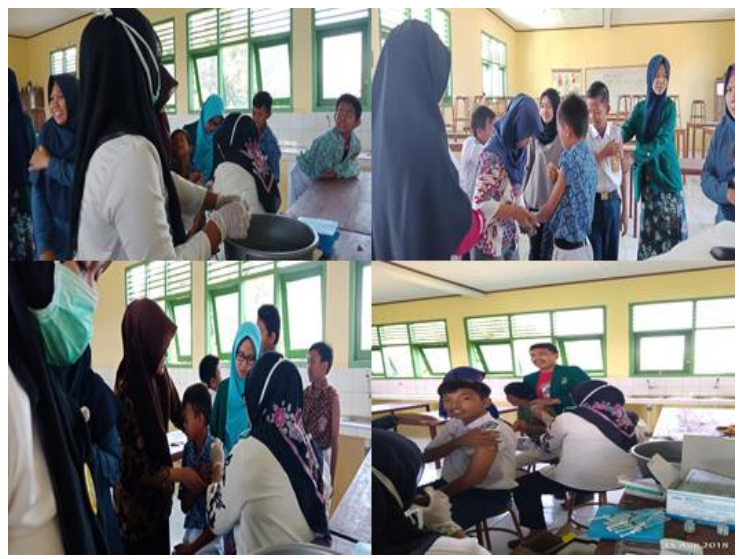

Vaksin

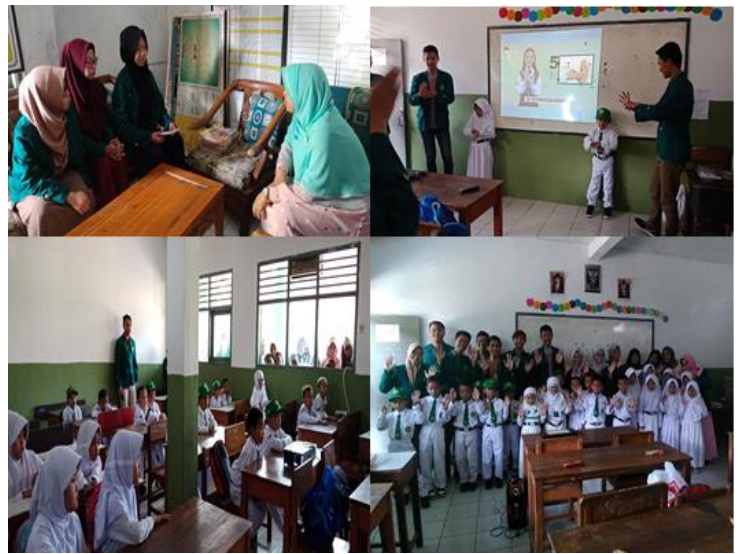

PHBS (Cuci Tangan) 


\section{Pemberdayaan Lingkungan}

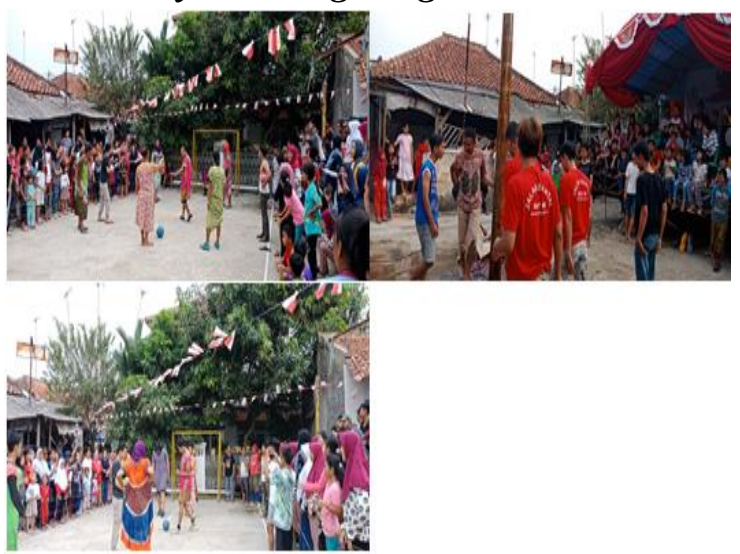

Acara perlombaan 17 agustus

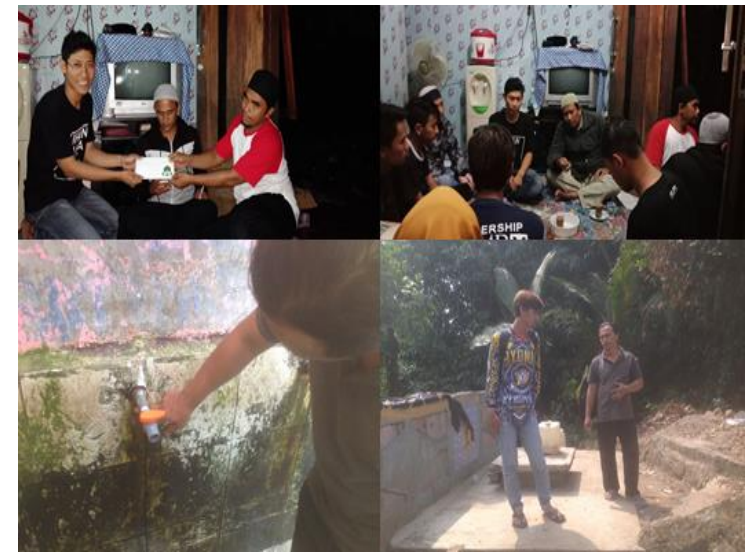

Renovasi MCK/Memberikan bantuan dana MCK

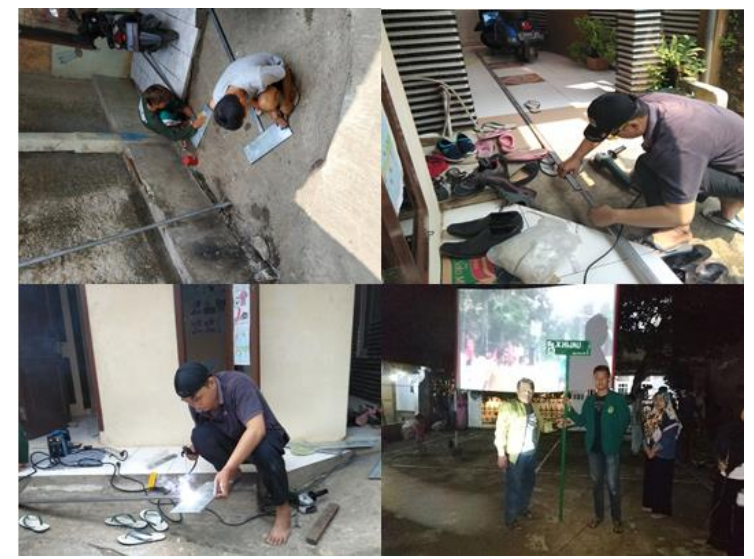

Pembuatan Plang

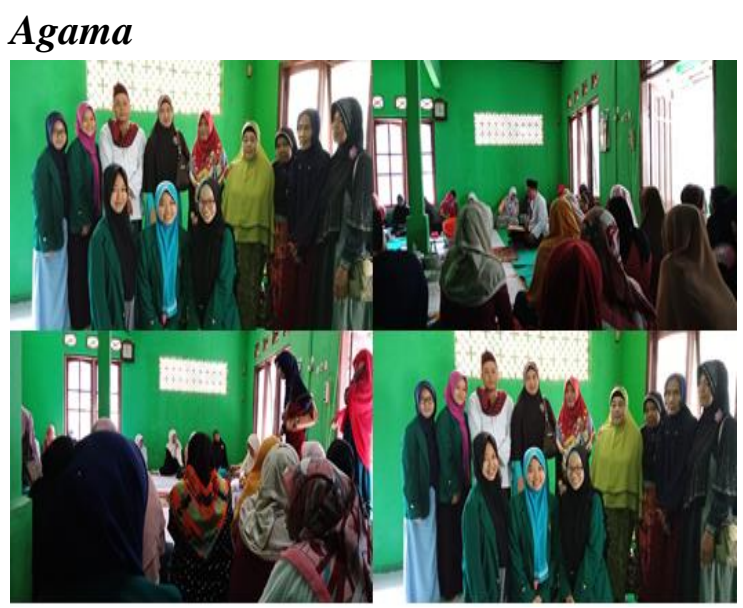

Pengajian rutin hari sabtu

\section{KESIMPULAN}

Pelaksanaan Kuliah Kerja Nyata (KKN) Tematik Terintegrasi Universitas Ibn Khaldun Bogor tahun 2018 di Desa Cimanggu Dua Kecamatan Cibungbulang Kabupaten Bogor selama kurang lebih 30 hari berjalan dengan baik dan lancar. Program yang dilaksanakan meliputi 4 bidang (pendidikan, ekonomi dan kesehatan dan pemberdayaan lingkungan). Dalam pelaksanaan program kerja pada setiap bidang dapat dikatakan berjalan dengan baik. Dan partisipasi serta dukungan masyarakat yang cukup tinggi, dimana masyarakat turut aktif dalam program kegiatan kami sehingga masyarakat dapat mengambil manfaatnya.Walaupun program KKN UIKA 2018 berjalan lancar, namun ada beberapa kendala dan hambatan dalam pelaksanaan program, seperti sulitnya mengumpulkan masyarakat ketika awal menjalankan program KKN dan kurangnya persiapan ketika pelaksanaan program KKN Tematik Terintegrasi.

$$
\text { Dampak bagi masyarakat }
$$

Masyarakat banyak sekali, mulai dari pendidikan, menjadikan warga lebih memotivasi anak-anak untuk terus 
semangat belajar, begitupun dengan ekonomi, kesehatan di wilayah setempat khususnya para generasi muda tumbuh jiwa kewirausahaan, kesadaran akan kesehatan lingkungan sehingga orang tua merasa terbantu dan bangga anak-anak nya menjadi penerus untuk bisnis dan terus selalu menjaga kesehatan serta mempererat keaktifan lingkungan efek dari program yang terlaksana.

\section{SARAN}

Adapun saran yang kami sampaikan pada laporan KKN ini adalah untuk Desa Cimanggu Dua yaitu, hendaknya mengerti bahwa kegiatan KKN bahwa bukan hanya untuk kepentingan mahasiswa saja tetapi kepentingan masyarakat desa setempat, dimana mahasiswa hanya sebagai motivator yang membantu memecahkan masalah sehingga diharapkan partisipasi desa dalam setiap program kerja $\mathrm{KKN}$ dapat lebih tinggi kedepannya.

\section{REFRENSI}

Muhammad Noor, "Pemberdayaan Masyarakat", Jurnal Ilmiah, vol 1 , No 2, hlm. 59.

Suharto Edi, 2010, Membangun Masyarakat Memberdayakan Rakyat(Bandung: Refika Aditama)

Soetomo, 2013, Masalah Sosial dan Upaya Pemecahannya (Yogyakarta: Pustaka Pelajar)

Totok Mardikanto, 2012 Pember-dayaan Masyarakat. Bandung: Penerbit Alfabeta.Hlm. 32 